\title{
A Brief Study on the Influence and Countermeasures of Network Technology for College Teaching Management
}

\author{
Lili Liu ${ }^{1, a^{*}}$ and Xuehong Chang ${ }^{1, b}$ \\ ${ }^{1}$ Jilin Agricultural University, Changchun, 130118, China \\ aliulili777@@163.com, ${ }^{\mathrm{b}} 66414623 @ q q . c o m$
}

Keywords: College teaching management; Network technology; Countermeasures

\begin{abstract}
After entering into the new era, our network technology develops rapidly, and its open, resource sharing and cooperative features, to a large extent, are affecting the college teaching management. We have to positively understand the characteristics of network technology as well as the effect on college teaching management. Thus, we should take targeted countermeasures ti improve the teaching management level.
\end{abstract}

\section{Introduction}

At present, college teaching management widely adopts network technology, which actually plays a pivotal role. However, a series of problems emerge too, which has bring about big challenges for college teaching management. Concerning this situation, we have to scientifically analyze and take targeted countermeasures based on real situation.

\section{The Application Advantage of Network Technology for CollegeTeaching Management}

Properly Distribute the Teaching Management Resources and Human Resources. According to researches, by taking advantage of network technology, we are able to break the traditional mode, resources distribution mode and properly distribute the human resources and teaching management resources. In addition, while strengthening the teaching management network information level, we are able to adopt the internet to reasonably distribute the resources throughout the school, at the same time, human resources, capital resources will be saved and the management efficiency as well as work efficiency will be improved.

The Original Pyramid Organization Management Structure Will be Improved. Researches found out that, parts of colleges are still adopting the hierarchical management structure which refines the work with excessive working staffs. As a result, there are reacted management level during the management process, so the working efficiency is not ideal. By taking advantage of network technology in college education management, we can carry out management work based on network and leaders can directly assign tasks and needs to avoid the middle level, which cannot only save human resources as well as management resources but also perfect working efficiency.

Help School Leaders to Make Scientific Decisions. Network technology is beneficial to construct college education management system and can realize informationization and transparency, which can directly report concrete data and details to managers so as to conduct scientific and advanced decisions. If the teaching management system implements based on network, then we are able to realize integration of online services. In the process of making decisions, we can timely understand the students, management condition so as to make more realistic decisions.

\section{Problems of Network Technology Application in College Teaching Management}

Overflow Pornographic Information and Moral Issues. With the development of times, the network technology directly affects the development of society. However, it also brings about new problems: for example, there are too much pornographic information while relative departments did not carry out scientific management to deal with the problems so there is a big threaten on the 
overall development of computer. In addition, young people do no have mature values and are bot able to distinguish bad or good, so a series of educational problems will occur.

Overflow of Online Games. The development of network technology, to a large extent, pushes the development of online games and many students are engaged in the online games, which will cause negative psychological problems. For example if they are engaged in the virtual world too much, the real reaction in real world will be ignored and they will become indifferent to classmates. What's more, if some students pau too much attention to online games and relay on the smooth virtual world, they will be unable to face difficulties in the society and lose serving sprit.

Contradiction between Network Technology Equipment and Education Administration. The continuous reform of network technology also asks continuous development of teaching management system. Colleges should keep pace with the time and timely update the network technology application equipment so as to make the network technology be adopted to the network requirement. However, enough funds should be invested and human resources have to update the network technology equipment. Colleges is mostly public, which do not take profits as the goal so they don't have advantages in terms of capitals. Therefore, it will be impossible to update network technology equipment, which will inevitably affect the construction of teaching management system.

\section{Application of Countermeasures for Using Network Technology in College Teaching Management}

College Managers should Build up the Idea of Modern Management Education. While adopting network technology, college teaching mangers should build up the ideas of modern management to keep a close eye on the requirement of times. What's more, managers should fully pay attention to the teaching management systems construction and deeply dig into the basic characteristics and functions of network, at the same time, experience the real function of network technology. For example, they can experience its interactive, equal and open natures. Meanwhile, college managers should change their role to become pioneers. During the process of constructing college teaching management system, we have to build an open one to make the commutation with students smoothly. Only by this, can we better manage students and improve working efficiency. In addition, the application of network technology will contribute to the fact that experienced educators will not longer have advantages. Concerning this situation, college educators should have a sense of competition to positively learn network technology and discipline themselves so as to develop teaching management.

Add Capitals on Network Technology for College Teaching Management. Network equipment will be updated quickly, therefore, during the process of network technology development, we have to timely update the equipment. However, colleges do not have enough money, so they have to positively seek the support of government and relative education department to add capitals to help colleges update the old and out-dated equipment.

Strengthen College Students' Moral Consciousness . At present, most students do not have good network moral consciousness, which should be paid attention to by ratline departments. What's more, teachers should help to carry out relative work to help improve the morality of students and improve their healthy growth. In real ideological and political education, teachers should take full advantage of network culture to lead students to correctly judge it and enrich their life, and meanwhile set up a correct life value, and worldview. Only by fundamentally improve students' online moral quality, can we solve relevant problems.

Improve the Network Technology Ability of College Managers. We have to continuously improve the network ability of college managers and properly select working staffs to ensure their basic quality. That is to say, we have to strength the quality of faculties and scientifically integrate the team to improve the proper application and health development of network technology. The network application ability of college mangers cannot only demonstrate the profession of the college but also contributes to the long-term development of schools, which should be highlighted.

Promote Flexible Learning Scheme. By combining the rules and guidance of various 
departments and schools, students should comprehensively taken consideration into their own intreats, basic ability and social requirement to take the initiative to choose courses and teachers; besides, education fees should be paid based on credits and they can graduate after finishing their credits. At the same time, students should properly delay or make their graduation ahead of time while schools make it possible that students can study and do part-time job. By implementing credit system and flexible system, students' passion will be ignited which actually show the philosophy to teach students in accordance with their aptitude and is able to better cultivate interdisciplinary talents. Meanwhile, the society will find more talents to fit jobs. Under this mode, we do not ask students to continually finish their academic year but properly arrange their time based on their ability. Furthermore, schools should vigorously develop entrepreneurship and students can get scholarship and tuition fees based on their ability, which can release the pressure of their family and cultivate their abilities. All in all, it is conducive to develop students and help with growth.

\section{Conclusions}

To summarize, informationaization and network is becoming more and more popular and college teaching management offices should keep pace with the rime to positively apply network technology to construct the education system. By applying network technology, we can effectively improve the college teaching management ability and ask higher requirement on faculties to encourage them to improve themselves, summarize experience so as to give scientific guidance and deepen the educaironm reform.

\section{References}

[1] Rendong $\mathrm{Hu}$. Influence and countermeasures of network technology for college teaching management [J]. Journal of Shandong Youth Administrative Cadres College, 2015,6(10): 123125. (In Chinese)

[2] Shuyi Chen. Influence and countermeasures of network technology for college teaching management [J]. Journal of Shandong Agriculture and Engineering University, 2014,5(19): 6668. (In Chinese)

[3] Shanhan Su, Liu Ji. Influence and countermeasures of network technology for college teaching management [J]. Test, 2015,7(18): 88-89. (In Chinese)

[4] Tenghai Lu. Influence and countermeasures of network technology for college teaching management [J]. Science \& Research, 2015,9(11): 244-245. (In Chinese)

[5] Yong Li. Countermeasures to deal with the effect on college teaching management practice caused by network technology. Journal of Changchun Education Institute, 2015,9(11): 77-78. (In Chinese)

[6] Liu Qin. Study on the influence and countermeasures of network technology for college teaching management. China Computer \& Communication, 2014,7(15): 233-235. (In Chinese) 